\title{
Factors Related To The Stroke Incidence In Women Post-Menopause At Ruang Seruni Ulin Hospital Banjarmasin
}

\author{
Rifa'atul Mahmudah ${ }^{1} *$ \\ ${ }^{1}$ Department of Sciences Nursing, STIKES Sari Mulia, Banjarmasin Indonesia \\ rifa_atul_mahmudah@stikessarimulia.ac.id
}

\author{
Munawarah $^{1}$ \\ ${ }^{1}$ Department of Sciences Nursing, STIKES Sari Mulia, Banjarmasin Indonesia \\ munawarah@gmail.com
}

\author{
Mahpolah ${ }^{2}$ \\ ${ }^{2}$ Poltekkes Kemenkes, Banjarmasin Indonesia \\ mahpolah@gmail.com
}

\begin{abstract}
Objective: The research aims to identify the factors related to the stroke incidence of postmenopause women at Seruni Room of Ulin Hospital Banjarmasin.

Technology or Method: This study used analytical surveys with case-control design. The population is women of post-menopause at Seruni Room of Ulin Hospital Banjarmasin with sample consisting of 40 people. The data were analyzed with chi-square and Fisher's exact test with $\alpha=0.05$.

Results: There is a correlation between the stroke incidence with the ages with value of $p=$ 0.000 . Family disease history with the stroke incidence with the value of $p=0.002$. Longterm menopause with stroke incidence with the $\mathrm{p}$ value $=0.004$ and there was correlation with obesity with the stroke incidence by the value of 0.008 of women of post-menopause at Ulin Hospital Banjarmasin.

Conclusion: There was a meaningful relationship among age, family disease history, old menopause and obesity with the stroke incidence of post-menopause women at Ulin Hospital, Banjarmasin
\end{abstract}

Keywords: Age, Family Disease History, Obesity, Old Menopause.

\section{INTRODUCTION}

In the year of 2010, Indonesia entered the era of globalization, the era of the commencement of the ASEAN free market which in those days have started happening a transition period or a shift in the pattern of community life where patterns of traditional community life turned into an advanced society. This situation causes the impact on the aspects of community life, especially the health aspects of urbanization, environmental pollution, accidents, as well as the increasing incidence of infection diseases, malnutrition and lack of healthy residential population [1].

Stroke is still the second leading cause of death in the world after heart disease. According to WHO, every year 15 million people around the world have a 
stroke. About 5 million suffer from permanent paralysis [2].

In the United States, stroke is the fourth leading cause of death after heart disease, cancer, and chronic lower respiratory tract diseases. Stroke is one of the causes of the 20 deaths in the United States. Every 40 seconds there is one person who suffered a stroke and every 4 minutes there is one person died of the stroke [3].

The prevalence of stroke in Indonesia is based on a health worker diagnosis of 7 per mile and diagnosed with symptoms of 12.1 per mil. The prevalence of stroke is based on the highest diagnosis of health workers in North Sulawesi (10.8), followed by Yogyakarta (10.3), Bangka Belitung and DKI Jakarta respectively 9.7 per mile. In South Kalimantan, the prevalence of stroke sufferers diagnosed by health worker is 9.2 and diagnosed with symptoms as 14.5 [3]

According to Ministry of Health Indonesia [4], Indonesian women who entered menopause in 2002 are $7.4 \%$. That number increased to $11 \%$ in 2005 . Then, it rose again by $14 \%$ by 2015 .

The data from BPS in 2009 that 5.320.000 Indonesian women have entered menopause per year. Ministry of Health Indonesia [4], estimates the population of Indonesia in 2020 will reach 262.6 million people with the number of women who live in menopause age about 30.3 million people with the average age of menopause 49 years.

Petrea (2009) found that the incidence of stroke increased in every decade of life in women and men. Among those aged $45-58$ years, the incidence of stroke for men is higher than women. The influence of gender-reversed in the oldest group, with a higher incidence of stroke in women than in men among those aged 8594 years. Women were significantly older on stroke the first time with an average age of 75 years in women than the age of 71 years in men [4.]

The data at Ruang Seruni Ulin Hospital Banjarmasin, which counted from January-November 2015, data of menopausal women with hemorrhagic stroke are 96 patients, while nonhemorrhagic stroke was 120 patients (Ulin Hospital Banjarmasin, 2015). From the preliminary study on December 01, 2015 at Ruang Seruni Ulin Hospital Banjarmasin conducted by observation, obtained from 10 stroke patients in postmenopausal women who were hospitalized, there was an age suffered in stroke were as 7 people $(70 \%)$ of women aged 65-74 years, and 3 people $(30 \%)$ of $>75$. While there was a family history were 5 people $(50 \%)$, if there is no family history were 5 people (50\%), 7 people (70\%) the length menopause were 20-30 
years, 3 people $(30 \%)$ were $>31$ years, While in obese with lean criteria: BMI $<18.5$ were 5 people (50\%), Normal: IMT $\geq 18,5-25$ were 3 (30\%), Obesity: IMT $\geq$ 27,0 There were 2 persons (20\%).

Research Objectives: The general objective is to investigate factors related to stroke incidence in post-menopausal women at Ulin General Hospital Banjarmasin.

\section{METHOD}

The research location at Ruang Seruni Ulin Hospital Banjarmasin. The research time was in April - May 2016. The method used was analytic survey, with case-control design (control case). Population in this study were all postmenopausal women at Ruang Seruni Ulin Hospital Banjarmasin from January to November 2015, 20 people with average monthly amounted to 216 people. The sample in this study amounted to 40 people (20 who had a stroke and 20 people who did not experience). With the sample criteria are as follows: postmenopausal stroke women age $>45$ years, obesity, with postmenopausal stroke postmenopausal women $\geq 27.0$ and $\mathrm{IMT} \leq 27.0$, family history, postmenopausal stroke women present or not there is a history of cardiovascular disease in the family (father and mother) and long menopause, long time menopause at the time of stroke.
While the control criteria included: postmenopausal women age> 45 years, obesity, with postmenopausal women $\geq$ 27.0 and $\mathrm{IMT} \leq 27.0$, family history, postmenopausal women or no family history of cardiovascular disease (fathers and mother) and long menopause, menopausal long time. Sampling took place from April to May 2016. The statistical tests used by the researchers were chi-square and Fisher's exact test using computerized $\alpha=0.05$.

\section{RESULTS}

1. Univariate Analysis 
Table 1 Distribution of age frequency, family history of disease, menopause, obesity and stroke incidence in postmenopausal women $(\mathrm{n}=$ 40)

\begin{tabular}{lcc}
\hline \multicolumn{2}{c}{ Variable } & $\%$ \\
\hline $65-\geq 75$ years old & 19 & 47,5 \\
\hline$\leq 45-64$ years old & 21 & 52,5 \\
\hline History of stroke in the & & \\
family & & \\
\hline Yes & 20 & 50 \\
\hline No & 20 & 50 \\
\hline Lenght menopause & 19 & 47,5 \\
\hline $11-\geq 21$ years old & 21 & 52,5 \\
\hline$\leq 9-10$ years old & & \\
\hline \multicolumn{1}{c}{ Obesity } & 7 & 17,5 \\
\hline Obesity & 33 & 82,5 \\
\hline Not obesity & 20 & 50 \\
\hline stroke incidence & 20 & 50 \\
\hline Stroke & & \\
\hline Not stroke &
\end{tabular}

Table 1 Show that age in post menopausal women most have age $\leq 45-64$ year that is 21 people $(52,5 \%)$, family disease history in post-menopausal women that have family disease history that is 20 people $(50 \%)$, long menopause in postmenopausal women $\leq 9-10$ years old were 21 people $(52.5 \%)$, obesity in postmenopausal women who did not have obesity amounted to 33 people $(82.5 \%)$ and stroke incidence in post-menopausal women who had a stroke which amounted to 20 people (50\%). and who did not have stroke that amounted to 20 people $(50 \%)$

2. Bivariate Analysis
Table 2 The relationship between age and stroke incidence in postmenopausal women

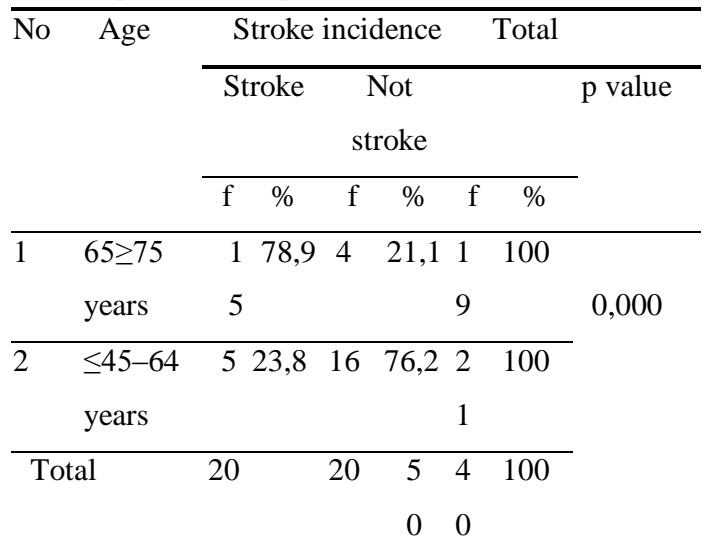

Table 2 Indicates that in postmenopausal women who experienced stroke incidence most of the aged $\leq 65-75$ years were 15 people $(75 \%)$ and those without stroke most of the $\leq 45-64$ years were $16(80 \%)$

Based on the result of statistical calculation with the chi-square test, $\mathrm{p}=$ 0.000 with $\alpha=0.05$ then $\mathrm{p}<\alpha$ so Ho is accepted.

Table 3 The relation history of family disease with stroke incidence in postmenopausal women

\begin{tabular}{|c|c|c|c|c|c|}
\hline \multirow[t]{3}{*}{$\overline{\mathrm{Nc}}$} & \multirow{3}{*}{$\begin{array}{l}\text { History } \\
\text { of } \\
\text { family } \\
\text { disease }\end{array}$} & \multicolumn{2}{|c|}{$\begin{array}{c}\text { Stroke } \\
\text { incidence }\end{array}$} & \multirow[t]{2}{*}{ Total } & \multirow{3}{*}{$\begin{array}{c}\mathrm{p} \\
\text { value }\end{array}$} \\
\hline & & Stroke & $\begin{array}{c}\text { Not } \\
\text { stroke }\end{array}$ & & \\
\hline & & f \% & f $\%$ & $\%$ & \\
\hline 1 & Yes & 1575 & $5 \quad 25$ & 20100 & \\
\hline 2 & No & $\begin{array}{ll}5 & 25\end{array}$ & 1575 & 20100 & 0,002 \\
\hline \multicolumn{2}{|c|}{ Total } & $20 \quad 50$ & 2050 & 40100 & \\
\hline & $1 \mathrm{a}$ & 3 & Show & that & \\
\hline
\end{tabular}
menopausal women who had a stroke most had a family history of 15 people $(75 \%)$ and who had no stroke most had no family history of 15 people $(75 \%)$. 
Based on the result of statistical calculation with chi-square test, $\mathrm{p}=0.002$ with $\alpha=0.05$ then $p<\alpha$ so Ho is accepted.

Table 4 Lenght menopausal relationship with stroke incidence in postmenopausal women

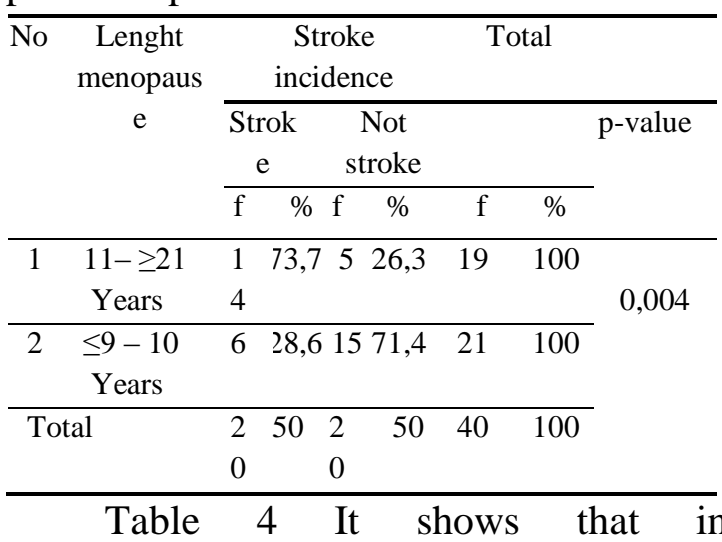
postmenopausal women with stroke most of length menopausal $11-\geq 21$ years was 14 people (70\%) and those who did not have stroke mostly experienced menopause $\leq 9$ 10 was 15 people $(75 \%)$.

Based on the results of statistical calculation with chi-square test, $p=0.004$ with $\alpha=0.05$ then $\mathrm{p}<\alpha$ so Ho is accepted.

Table 5 The relationship of obesity with the incidence of stroke in postmenopausal women

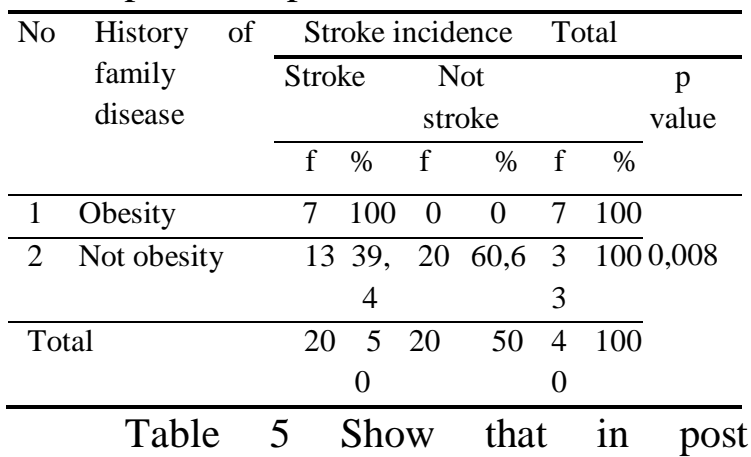
menopausal women who experience stroke mostly obesity amounted to 7 people $(35 \%)$ and who did not have stroke mostly not obesity amounted to 20 people (100\%).
Based on the results of statistical calculations with fisher's exact test obtained $p=0.008$ with $\alpha=0.05$ then $p<\alpha$ so Ho accepted.

\section{DISCUSSION}

1. Age in postmenopausal women

The results of this study showed that the age in postmenopausal women treated in Seruni Room Ulin General Hospital Banjarmasin with age $\leq 45-64$ years, amounted to 21 people $(52.5 \%)$

19 people (47.5\%) postmenopausal women who have $65-\geq 75$ years of age can be said that they are more at risk for stroke, this is because in postmenopausal women older than $65-\geq 75$ years of all the organs will experience function decline including brain blood vessels making it more prone to stroke[5]. In addition to postmenopausal women who have age 65$\geq 75$ years, there are 21 people $(52.5 \%)$ postmenopausal women who have age $\leq 45-64$ years.

2. Family disease history in postmenopausal women

The results of this study showed that family history of postmenopausal women who were treated had a family history of 20 persons (50\%).

From 20 respondents postmenopausal women with a family history of the disease, it can be concluded that people with a family 
history are at high risk for stroke because if a defect in the form of a cadasil is probably the most influential genetic factor another stroke risk [6].

In addition to postmenopausal women who have a family history of illness, there are $20 \quad(50 \%)$ postmenopausal women without a family history of disease, although no family history of the disease would be said to be at risk for stroke if they were over 55, obese, life and unhealthy lifestyles such as smoking habits, consuming soft drinks and alcoholic fruits like fast food and junk food and lack of motion/exercise activity.

In this study, we found 10 people (50\%) postmenopausal women who have a family history of diseases, someone who has a family history of illness that is derived from his mother is at risk of stroke due to a genetic decrease derived from the mother.

3. Lenght menopause in postmenopausal women

The results of this study showed that menopause in postmenopausal women treated in the Seruni Room Ulin General Hospital Banjarmasin that experienced $\leq 9-10$ years old amounted to 21 people $(52.5 \%)$.

Of the 19 men $(47.5 \%)$ postmenopausal women who experienced a long-term menopause of $11- \pm 21$ years can be said that they are more at risk of stroke, this is because in postmenopausal women who experienced menopause $11-\geq 21$ years will decrease production of the hormone estrogen thus leading to a decrease in HDL where HDL plays an important role in preventing the process of atherosclerosis [9].

In addition to postmenopausal women who have a long-term menopause of $11-\geq 21$ years, there are 21 people $(52.5 \%)$ postmenopausal women who have long menopause $\leq 9$ 10 years, this does not close the possibility of stroke even though stroke most often found in people who have had menopause for more than 10 years but there are also people who suffered a stroke in menopause long after less than 10 years this can be caused by obesity [10].

4. Obesity in postmenopausal women

The results of this study showed that obesity in postmenopausal women was not obesity amounted to 33 people $(82.5 \%)$.

Of 7 people $(17.5 \%)$ postmenopausal women who are obese can be said that they are more at risk of stroke, this is because in postmenopausal women who are obese will lead to increased heart work in 
pumping blood throughout the body, which can increase blood pressure, besides obesity can also accelerate the process of arteriosclerosis [9].

In addition to postmenopausal women who are obese, there are 33 people $(82.5 \%) \quad$ postmenopausal women who are not obese does not close the possibility of stroke, although stroke is most often found in people who are obese.

5. Stroke incident at Ulin General Hospital Banjarmasin

The results of this study showed that the incidence of stroke in postmenopausal women who suffered a stroke that amounted to 20 people (50\%) postmenopausal women who suffered a stroke were caused by some of the first factors of postmenopausal women in this study were mostly over 55 years old, the theory that after 55 years of age increased the risk of stroke This is caused by the decline in organ function in the body including the blood vessels of the brain so more susceptible to stroke. The second factor was a family illness history in this study. There were 20 postmenopausal women with a family history of this disease due to a defect in the form of blood vessels that were lowered from family members suffering from previous strokes. The third factor was menopausal duration in this study 19 people $(47.5 \%)$ postmenopausal women who had menopause 11- \pm 21 years old, theorists say people who have 10 years of menopause> 10 years will double the risk of stroke this thing caused by a decrease in estrogen hormone production resulting in decreased HDL so it will be more susceptible to stroke. The fourth factor is obesity in this study. There are 7 people who are obese and all suffer from stroke, the theory says that people who are obese are at risk of stroke, obesity will lead to increased heart work in pumping blood throughout the body, so it can increase blood pressure, can also accelerate the process of atherosclerosis.

6. The relationship between age and stroke in postmenopausal women

The results of this study showed that in postmenopausal women who experienced stroke incidence most of the age of $65-\geq 75$ years amounted to 15 people (78.9\%) and who did not experience stroke most ages $\leq 45-64$ years amounted to 16 people $(76,2 \%)$.

Based on chi-square test results obtained $\mathrm{p}$-value $=0.000$ then $\mathrm{p}<\alpha$ so there is a significant relationship between age with stroke incidence in 
post menopausal women at ruang Seruni Ulin Hospital Banjarmasin

The results of this study obtained many elderly people affected by stroke at age $65-\geq 75$ years this could be due to the aging process, where all the organs of the decline in function including the blood vessels of the brain. Blood vessels become inelastic, especially the endothelial thickening of the intima, causing the lumen of blood vessels to become narrower and affect the decrease of cerebral blood flow.

The results of this study also found there are 5 postmenopausal women $(25 \%)$ who suffered a stroke at age $\leq 45-64$ years this could be caused by other factors such as family history of disease and obesity in this study the five postmenopausal women who suffered a stroke on ages $\leq 45-64$ all have a history of family illness and obesity it is this that may cause men keliama people have a stroke.

Stroke is most common among people in old age, although there are also stroke-related attacks in middle age. Older age will increase the risk of stroke, not only because of the physiological system of the body, especially the old persyarafan system so it can not be given heavy work, but also usually, the increasing age, will make a lot of things to think about to aggravate nerve work [10].

The results of this study are consistent with the results of the Rothwell [10] study which found that the percentage of age group $>55$ years, suffered more stroke compared to the age group 40-55 years.

7. The relationship between family history of the disease and the incidence of stroke

The results in this study showed that in post-menopausal women who had a stroke most had a family history of 15 people $(75 \%)$ and those without stroke most had no family history of 15 people $(75 \%)$. Based on chi-square test results obtained $\mathrm{p}$ value $=0.002$ then $\mathrm{p}<\alpha$

The results of this study found 15 people $(75 \%)$ post-menopausal women who suffered a stroke because there has a family history of this disease is caused by a defect in the form of blood vessels derived from parents.

The results of this study found 5 post-menopausal women (25\%) who did not have a history of stroke in the family, but the stroke. This is often due to unhealthy diet and lifestyle, such as smoking, drinking alcohol, and eating instant food. So, if one family member suffered a stroke, 
other family members should be wary of that possibility. But there must be steps to make lifestyle changes, and make a healthy lifestyle[10].

8. The relationship between the lenght menopause with the incidence of stroke in postmenopausal women

The results of this study showed that in postmenopausal women who had a stroke most of the lenght menopause $11-\geq 21$ years was 14 people $(73.7 \%)$ and who did not have stroke mostly experienced menopause $\leq 9-10$ of 15 people ( $75 \%$ ). Based on the results of statistical calculations with chi-square test, $\mathrm{p}=0.004, \mathrm{p}<\alpha$.

The results of this study found that 14 people postmenopausal women had a stroke at $11-\geq 21$ years length menopause this is caused by the decrease in estrogen production that plays a role in increasing $\mathrm{HDL}$, in which $\mathrm{HDL}$ plays an important role in preventing the process of arteriosclerosis [6].

The results of this study also found there are 4 people (20\%) postmenopausal women who suffered a stroke in menopause length $\leq 9-10$ years this may be caused by other factors such as family disease history in this study the six postmenopausal women who suffered a stroke in the old menopause $\leq 9-10$ years all have a history of family diseases this is what is most likely to cause the six people to experience a stroke.

9. The relationship between obesity and the incidence of stroke in postmenopausal women

The results of this study showed that in post menopausal women who suffered a stroke mostly obese were 7 people $(100 \%)$ and those who did not have stroke most did not obesity amounted to 20 people $(60,6 \%)$.

Based on fisher's exact test results obtained $\mathrm{p}=0.008$ then $\mathrm{p}<\alpha$.

The results of this study found 7 people $(100 \%)$ postmenopausal women affected by stroke due to obesity is due to an increase in prothrombotic factors and also increased levels of C-reactive protein (CRP) contained in the body of someone who is overweight [7].

In this study, there were also 13 people (39.4\%) postmenopausal women who suffered a stroke despite having a normal weight. This could be due to other factors that can cause strokes, such as age, family history of the disease and long experience of menopause. Despite having a normal weight, lifestyle must be maintained so as not to cause other trigger factors that trigger a sudden stroke.

\section{CONCLUSION}


There is a significant relationship between age, family history, length, and obesity with stroke incidence in post menopausal women at Ruang Seruni Ulin Hospital Banjarmasin 2016.

\section{REFERENCES}

[1] Elizabeth AS, Linda SB, dan Maria A. 2013. Hubungan Gaya Hidup pada Pasien Hipertensi dengan Resiko Teradinya Stroke di Rumah Sakit Santo Borromeus Bandung.http://www.academia.edu/94 97252/Hubungan_Gaya_Hidup_Pada _Pasien_Hipertensi_Dengan_Resiko_ Terjadinya_Stroke. [diakses pada tanggal 11 Mei 2016]

[2] American Heart Associaton Guideline, 2006. Heart disease and stroke fact Dallas, texas: AHA [internet] tersedia dalam https://www.heart.org/HEARTORG /General/Heart-and-

StrokeAssociationStatistics: [diakses pada tanggal 10 Juni 2016].

[3] Sholichati Shofira, 2015. Pengaruh Kadar Hemoglobin Dan Hematokrit Terhadap Perubahan Skor Nihss (National Institute Health Of Stroke Scale) Pada Klien Stroke Iskemik. [Skripsi]. Banjarmasin: Program Studi Ilmu Keperawatan Sekolah Tinggi Ilmu Kesehatan Sari Mulia Banjarmasin

[4] Departemen Kesehatan Republik Indonesia. 2007. Riset kesehatan Dasar,
(Riskesdas). Jakarta: Departemen Kesehatan Republik Indonesia

[5] Kristiyawati, S.P., Irawaty, D., Hariyati, Rr.T.S. 2009. "Faktor Risiko yang Berhubungan dengan Kejadian Stroke di RS Panti Wilasa Citarum Semarang [internet] tersedeia dalam https://www. google.com/search [diakses pada tanggal 27 Nopember 2015]

[6] Petrea RE, Beiser AS, Seshadri S, Kelly-Hayes M, Kase CS, Serigala PA. Perbedaan Gender Dalam Insiden Stroke Dan Kecacatan Pasca Stroke Dalam Studi Framingham Jantung Stroke 2009; [internet] tersedia dalam http:pubmed. $\quad 40: . . \quad$ 1032-1037. [diakses pada tanggal 27 Nopember 2015]

[7] Gemari. 2008. Faktor resiko stroke. Gemari Edisi 94/Tahun IX/November 2008

[8] Kurth, T. 2005. Lipid levels and the risk of ischemic stroke in women.Neurology.20;68(8):556-562.

[9] Rothwell, P.M., 2008. Systematic Review of Methods and Result o f Studies of The Genet ic Epidemio logy of Ischemic Stroke. J Stroke 35: 2-227. http://stroke. ahajournals.org/

[10] Hananta Yuda, I Putu. 2011. Deteksi Dini dan Pencegahan 7 Penyakit Penyebab Mati Muda. Yogyakarta: Media Pressindo 